\title{
HAPLOTYPE AND MERISTIC VARIATIONS OF OREOCHROMIS NILOTICUS AND ITS HYBRIDS PRESENT IN SELECTED RESERVOIRS IN SRI LANKA
}

\author{
SP Samaradivakara ${ }^{1,3}$, NY Hirimuthugoda ${ }^{2 *}$ RHANM Gunawardana ${ }^{2}$, RJ Illeperuma ${ }^{3}$ ND Fernandopulle ${ }^{4}$, \\ AD De Silva ${ }^{4}$ and PABD Alexander ${ }^{1}$ \\ ${ }^{1}$ Department of Farm Animal Production \& Health, Faculty of Veterinary Medicine and Animal Science, Uni- \\ versity of Peradeniya, Sri Lanka \\ ${ }^{2}$ Department of Animal Science, Faculty of Agriculture, University of Ruhuna, Mapalana, Kamburupitiya. \\ ${ }^{3}$ Genetech, 54, Kitulwatte Road, Colombo 08, Sri Lanka \\ ${ }^{4}$ Genetech Research Institute, 54, Kitulwatte Road, Colombo 08, Sri Lanka
}

Accepted: $17^{\text {th }}$ June 2014

\begin{abstract}
The Nile tilapia, Oreochromis niloticus was introduced from Africa's to Sri Lanka in the 1970s. Since then tilapia has dominated in most of the reservoir fisheries in Sri Lanka. The genetic and meristic variation of the domesticated tilapia was studied using polymorphisms in mitochondrial DNA ( $m t$-DNA) and by analysis of morphometric and meristic characters. Ninety seven fish from three locations, namely Kurunegala, Anuradhapura, Polonnaruwa and ten control samples from the brood stock of the Udawalwe Tilapia Breeding Centre were collected. The genetic analysis targeted $16 \mathrm{Sr}$ region of mitochondrial genome. The Meristic analysis included fourteen meristiccounts, which were subjected to discriminant analysis and cluster analysis. The PCR- SSCP procedure of the $m t$ DNA resolved eight haplotypes that overlapped between the four locations. The meristic and the genetic composition were common within the three domesticated fish populations collected from Kurunegala, Anuradhapura, Polonnaruwa and the brood stock of the Udawalwe Tilapia Breeding Centre. The results of this study will significantly contribute towards new inferences regarding management of the brood stocks and the wild stocks of tilapia aquaculture.
\end{abstract}

Key words: O. niloticus, PCR-SSCP, Meristic

\section{INTRODUCTION}

Tilapias were introduced to Sri Lanka to facilitate the availability of inexpensive, high protein and low fat food staples. The Nile Tilapia, O. niloticus (Linnaeus, 1758) (Cichlidae; Teleostei), was first introduced into the country in 1975 (De Silva, 1997). Since its introduction to Sri Lanka, O. niloticusspecies have become widely distributed throughout many confined water bodies in the dry zone of Sri Lanka (Amarasinge and De Silva, 1996). After decades of introduction and stocking of the fish, they have highly adapted to a wide range of geographical locations and have shown phenotypic variations with respect to the tilapia strains of the brood stock. Meristic methods remain one of the simplest and most direct way among methods of species identification. Therefore analysis of phenotypic variation in meristic counts have been a method most com- monly used to delineate stocks of fish (Creech 1992; Mamuris et al. 1998 Bronte et al. 1999 Hockaday et al. 2000, Cadrin and Silva, 2005) and continues to have an important role in stock identification.

There have been no detailed studies of molecular genetic variation in Tilapia in Sri Lanka nor has the technique of Single Strand Conformation Polymorphism (SSCPs), which is being increasingly used to assay for genetic variation in fish species (Aurelle and Berrebi, 2001; Liu and Cordes, 2004), been applied to tilapia. The $m t$-DNA $16 \mathrm{Sr}$ region has a high nucleotide substitution rate, making it particularly useful for estimating the genetic population structure of closely related animal populations (Sivasundar et al. 2001; Vigilant et al. 1991).

In this context, we analyzed meristic polymor-

*Corresponding author: yasho@ ansci.ruh.ac.lk 
phism and the genetic diversity of tilapia fish populations by using SSCP analysis of the mitochondrial DNA (mtDNA) 16Sr control region, among one hundred and seven tilapia obtained from three locations, namely from $\mathrm{Ku}-$ runegala, Anuradhapura, Polonnaruwa District and from the brood stock of Udawalawe Tilapia Breeding centre. The present study therefore represents the attempt to investigate the variations observed in the tilapia populations/ stocks at the meristic level and the genetic diversity of domesticated populations of Tilapia in the three districts of Sri Lanka.

\section{MATERIALS}

During May - December 2011, a total of 97 samples were collected from reservoirs present in Kurunegala $(n=31)$, Anuradhapura $(n=25)$, and Polonnaruwa $(n=41)$. Fish were caught using cast nets. Ten samples of brood stock $O$. niloticus were collected from the Udawalawe Tilapia Breeding Centre. After capture the fish were delivered in ice for analyses.

\section{METHODOLOGY}

\section{DNA extraction}

DNA was extracted using Chelex 100 method using approximately $1 \mathrm{~mm}^{3}$ piece of muscle tissue from each fish.

PCR - Single Strand Confirmation Polymorphism (SSCP) of $m t$ - DNA

A target region of $550 \mathrm{bp}$ in size in the $16 \mathrm{Sr}$ gene of the mitochondrial genome was amplified by Polymerase Chain Reaction in a final volume of $25 \mathrm{ml}$ using sequence specific $16 \mathrm{Sar}$ forward - 5' CGC CTG TTT ATC AAA AAC 3' and 16Sbr reverse - 5' CCG GTC TGA ACT CAG ATC ACG T 3'(DNA bases 22) (Vences et al. 2005). DNA amplifications were carried out in a final volume of $25 \mu \mathrm{l}$, using 5 $\mu l$ of DNA extract as template. The amplification mixture contained $0.25 \mu \mathrm{l}$ of taq DNA Polymerase (5 units/ $\mu$ l, Geneshun), $2.5 \mu$ l of $10 \mathrm{X}$ buffer, $2.5 \mu \mathrm{l}$ of $25 \mathrm{mM} \mathrm{MgCl}_{2}, 0.5 \mu \mathrm{l}$ of 10
$\mathrm{mM}$ of each dNTPs, $0.5 \mu \mathrm{l}$ of $10 \mu \mathrm{M}$ of each primer (Integrated DNA Technologies) and $13.25 \mu \mathrm{l}$ of nuclease free water. The $1^{\text {st }}$ amplification cycle consisted of 1 min of initial denaturation at $95{ }^{\circ} \mathrm{C}, 40$ seconds of denaturation at $94^{\circ} \mathrm{C}, 1$ minute annealing at $50^{\circ} \mathrm{C}, 1$ minute extension $72^{\circ} \mathrm{C}$, for 6 cycles and the $2^{\text {nd }}$ amplification cycle consisted of 40 seconds of initial denaturation at $92^{\circ} \mathrm{C}, 45$ seconds of annealing at $54^{\circ} \mathrm{C}, 1$ minute extension $72^{\circ} \mathrm{C}$, for $36 \mathrm{cy}$ cles and final extension for 5 minutes at $72{ }^{\circ} \mathrm{C}$ in GeneAmp PCR system 9700 thermocycler (Applied Biosystems).

To identify haplotypes through SSCP, the PCR products $(7-8 \mathrm{ml})$ were run on a $6 \%$ non denaturing PAGE. SSCP products were visualized by Silver Staining method according to manufactures recommendations (Promega, USA). The resultant bands were scored by comparison with those of ten brood stock $O$. niloticus tilapia samples collected from the Udawalawe tilapia breeding center.

\section{Meristic Data Analysis}

\section{Measurements}

All measurements were taken on the left side of fish. A total of 14 meristic variables $(m)$, which were directly counted. After complete thawing, Meristic counts taken as prescribed by Roux (1971).

Meristic characters included, Number of the lateral line scales (LS), Number of the transverse scale (TS), Number of the predorsal scales (PrS), Number of the postdorsal scales (PoS), Number of scales surrounded the caudal peduncle (SCP), Number of the rays in the dorsal fin (RD), Number of the spines in the dorsal fin (SD), Number of the rays in the anal fin (RA), Number of spines in the anal fin (SA), Number of rays in the pectoral fin (RPec), Number of rays in pelvic fin (Rpel), Number of rays in caudal fin (RC), Vertebrae (V), Gill rackers in the lower part of the first $\operatorname{arch}(\mathrm{GR})$.

Discriminant analysis and cluster analysis was 
done on the raw meristic data. Prior grouping of the samples were done according to the number of identified haplotype. The fourteen meristic characters were taken as the variables. Meristic data of the fish belonging to each group/haplotype was analyzed using SPSS software package version 10.

\section{RESULTS}

\section{mt-DNA size variants (Haplotypes)}

Identification of haplotypes by SSCP is based on the difference of mobility of a singlestranded DNA that is determined by its con-

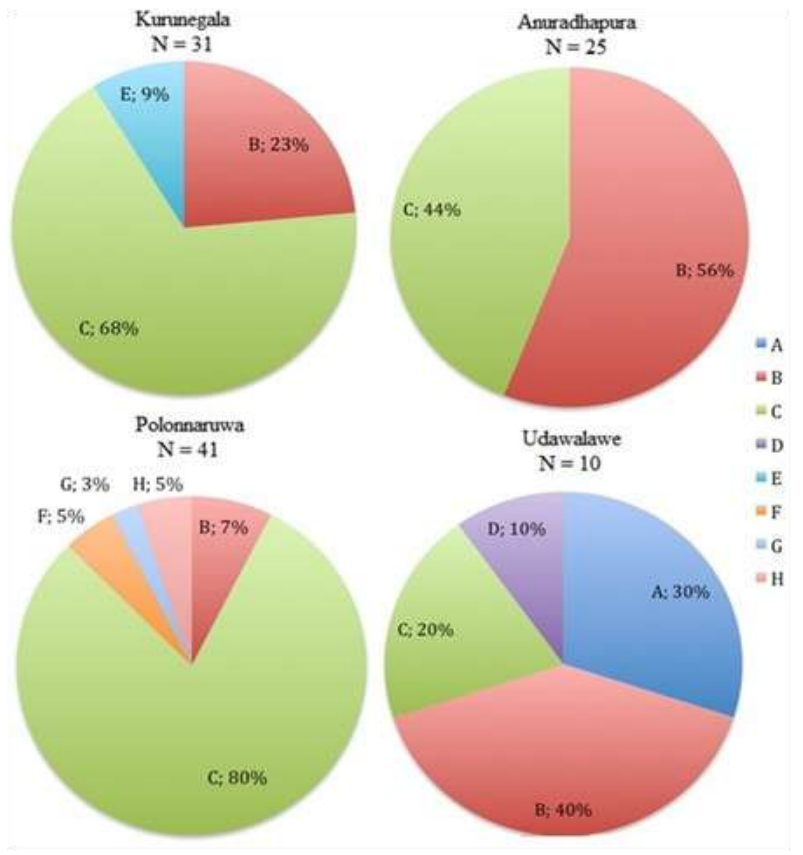

Figure1 : Frequency of haplotypes of Tilapia from each sampled area

Table 1: Summary of canonical discriminant functions firmation due to the sequence changes. We grouped the 107 fish into eight haplotypes named $-\mathrm{A} \|$ to $-\mathrm{H} \|$ (Figure 1). Out of eight, three haplotypes were observed from Kurunegala, two within Anuradhapura, five from Polonnaruwa and four haplotypes among brood stock samples.

Kurunegala, Anuradhapura and Polonnaruwa districts share the identified $-\mathrm{B} \|$ and $-\mathrm{C} \|$ haplotypes in common. Apart from these two haplotypes, -Ell haplotype was found only in Kurunegala district while $-\mathrm{F}\|,-\mathrm{G}\|$ and $-\mathrm{H} \|$ haplotypes were found uniquely in Polonnaruwa district. Out of the ten brood stock $O$. niloticus fish, six fish samples belong to the $-B \|$ and $-C \|$ haplotypes, which are commonly shared by the three districts and out of the remaining four brood stock O.niloticus fish, three fish samples belong to -All haplotype leaving the remaining fish sample belonging to the -D\|l haplotype (Figure 1).

\section{Meristic data analysis}

\section{Discriminant analysis of meristic data}

Prior grouping of the samples were done according to the eight haplotypes as group 1haplotype A, group 2- haplotype B, group 3 haplotype 3, group 4- haplotype 4 group 5haplotype 5 , group 6 - haplotype 6 , group 7 haplotype7, group 8- haplotype 8. Seven canonical discriminant functions were obtained (Table 1). The first two discriminant functions based on the meristic measurements together

\begin{tabular}{|c|c|c|c|c|c|c|c|}
\hline & Funct & & & & & & \\
\hline$m$ & 1 & 2 & 3 & 4 & 5 & 6 & 7 \\
\hline$\overline{\mathrm{LS}}$ & -.151 & .232 & -.407 & -.062 & .706 & .323 & .102 \\
\hline TS & .310 & -.566 & -.132 & -.022 & -.146 & -.126 & .553 \\
\hline PRS & -.149 & .073 & -.380 & .171 & .536 & .285 & -.045 \\
\hline POS & -.250 & .180 & .494 & -.457 & -.591 & .261 & .363 \\
\hline SCP & .287 & -.217 & .241 & -.068 & .254 & -.522 & -.209 \\
\hline $\mathrm{RD}$ & .024 & .327 & .516 & .089 & .177 & -.129 & .874 \\
\hline SD & .387 & .194 & .613 & .778 & .080 & -.146 & .062 \\
\hline RA & .496 & .137 & .276 & .210 & .184 & .435 & -.390 \\
\hline RPEC & -.626 & -.164 & -.071 & -.023 & .389 & .101 & -.581 \\
\hline RPEL & -.032 & .046 & .424 & -.074 & .236 & .027 & .170 \\
\hline $\mathrm{RC}$ & -.063 & -.585 & .157 & .104 & -.173 & .562 & .029 \\
\hline V & -.194 & .490 & -.380 & -.056 & -.590 & .133 & -.159 \\
\hline GR & .696 & .244 & -.104 & -.450 & -.012 & .193 & -.491 \\
\hline
\end{tabular}


Table 2: Classification results of stepwise discriminant analysis using Meristictic data

\begin{tabular}{|c|c|c|c|c|c|c|c|c|c|c|c|}
\hline \multirow[b]{2}{*}{ Haplotype } & \multirow{2}{*}{$\begin{array}{c}\text { Group } \\
\text { label }\end{array}$} & \multirow[b]{2}{*}{ Sample size } & \multirow{2}{*}{$\begin{array}{c}\text { Percent } \\
\text { correct }\end{array}$} & \multicolumn{8}{|c|}{ Number of fish classified into groups } \\
\hline & & & & $\mathbf{A}$ & B & $\mathbf{C}$ & D & $\mathbf{E}$ & $\mathbf{F}$ & G & $\mathbf{H}$ \\
\hline A & 1 & 3 & 66.7 & 2 & 0 & 1 & 0 & 0 & 0 & 0 & 0 \\
\hline B & 2 & 27 & 59.3 & 1 & 16 & 5 & 2 & 2 & 1 & 0 & 0 \\
\hline $\mathrm{C}$ & 3 & 68 & 51.5 & 9 & 13 & 35 & 3 & 6 & 1 & 0 & 1 \\
\hline $\mathrm{D}$ & 4 & 1 & 100 & 0 & 0 & 0 & 1 & 0 & 0 & 0 & 0 \\
\hline $\mathrm{E}$ & 5 & 3 & 66.7 & 0 & 0 & 1 & 0 & 2 & 0 & 0 & 0 \\
\hline $\mathrm{F}$ & 6 & 2 & 100 & 0 & 0 & 0 & 0 & 0 & 2 & 0 & 0 \\
\hline $\mathrm{G}$ & 7 & 1 & 100 & 0 & 0 & 0 & 0 & 0 & 0 & 1 & 0 \\
\hline $\mathrm{H}$ & $\underline{8}$ & -2 & 100 & $\underline{0}$ & 0 & 0 & 0 & 0 & 0 & 0 & 2 \\
\hline
\end{tabular}

explained $79.0 \%$ of the variability $(49.9 \%$ and $18.1 \%)$.

According to the canonical discriminant function coefficients obtained for meristic data, the most influential variables for function 1 were Number of the transverse scale (TS) : 0.310 ; number of spines in the dorsal fin (SD) : 0.387 ; Number of rays in the anal fin (RA) : 0.496 and Gill Rakers (GR) : 0.696 with respect to the discriminant function analyses on the meristic data, the correct classification rates ranged from $66.7 \%$ to $100 \%$, with an overall rate of $57 \%$ (Table 2).

The group graph derived from cluster analysis based on the meristic data was constructed for the eight haplotypes screened from Kurunegala, Anuradhapua, Pollonnaruwa and the Udawalwe tilapia breeding centre (Figure 2). The plot of the first two canonical variates shows a noticable overlap of samples belonging to haplotypes A, B, C, D, E . The haplotypes, F, G and $\mathrm{H}$ identified from Pollonnaruwa district showed a deviation from the rest of the haplotypes concentrating on to the left side of the graph. Haplotype group G is located in the negative part of the canonical function 1 .

\section{Cluster analysis of meristic characters}

The denogram derived from cluster analysis based on the meristic characters and the average linkage between groups, could not cluster the samples according to the haplotype groups. However the haplotype $\mathrm{G}$ was isolated from the haplotypes $\mathrm{F}$ and $\mathrm{H}$ which were more closely clustered together. Therefore a complete seperation of the haplotype groups according to the meristic characters could not be obtained (Figure 3).

\section{DISCUSSION}

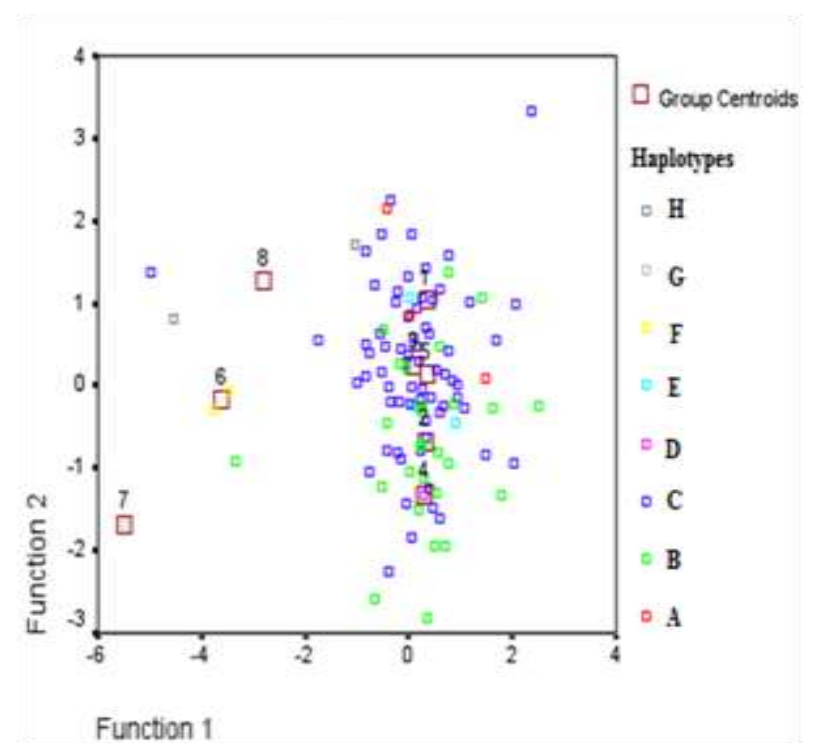

Figure 2:Meristic Counts Analysis Using Discriminant Analysis- Group Graph for all haplotypes

\section{Control region sequence variation and util- ity of the SSCP technique}

The SSCP analysis of $16 \mathrm{Sr}$ region of $m t$-DNA revealed moderately high haplotype diversity among tilapia in reservoirs of Kurunegala and Polonnaruwa. This is consistent with available data on high variability of $16 \mathrm{Sr}$ subunit in fish (Niyengi et al. 2009, Machordom et al. 2000). 


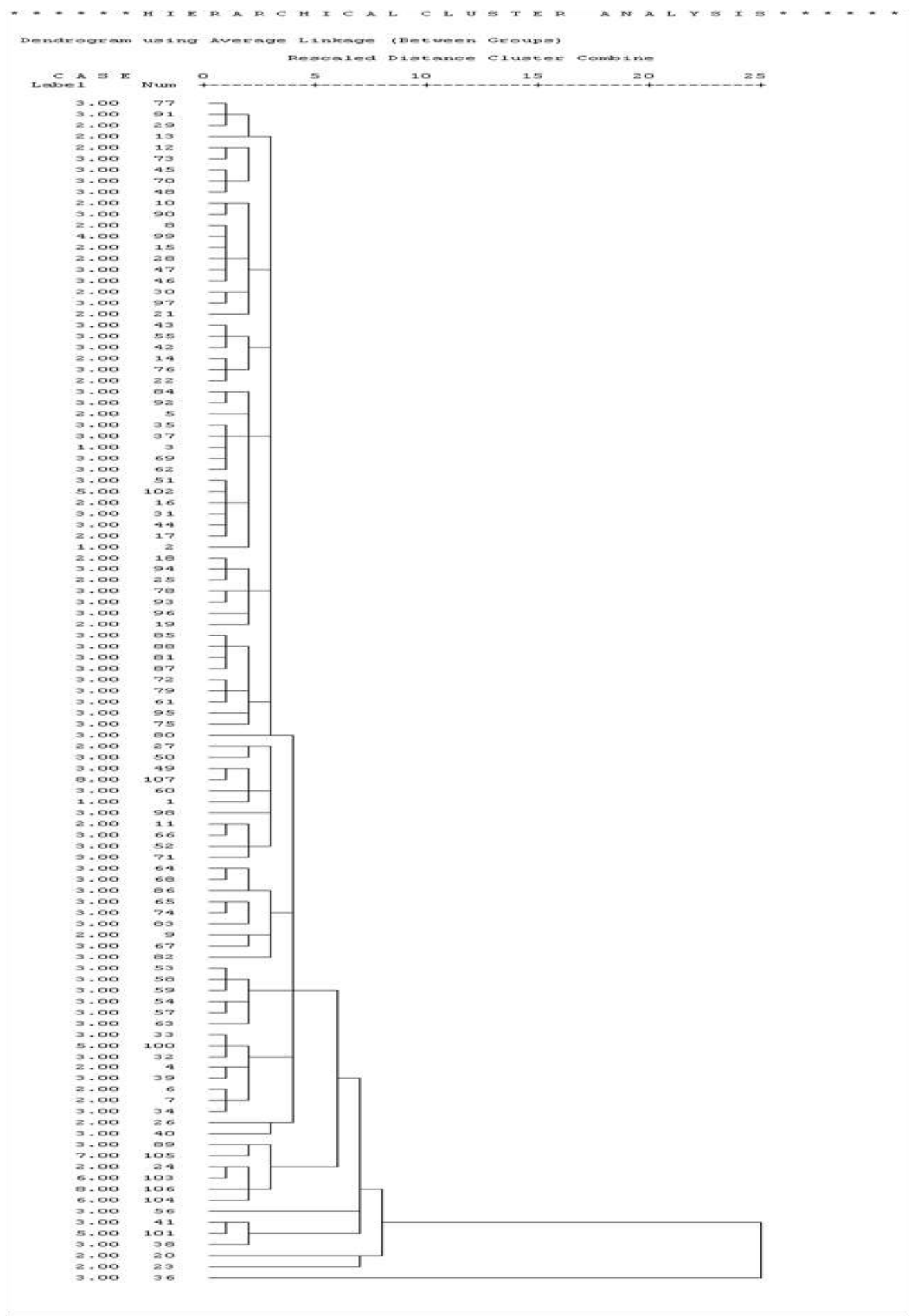

Figure 3: Dendrogram obtained for meristic characters of the collected fish

Thus, the variation detected using the SSCPs technique was sufficient to allow effective comparisons among samples, which revealed significant and contrasting patterns of variation within and between the locations for the populations of tilapia. 


\section{Haplotype and meristic variation in the population}

The present findings on distribution patterns with respect to the meristic characters indicate that the samples were not able to discriminate according to their haplotype groups. This could be that the selected reservoirs possess appropriate environmental conditions for the fish eliminating any drastic stress, such as polluted water (Kirchhoff et al. 1999) or salinity (Kamal and Mair, 2005), which could cause change in more predetermined characters such as meristics and the genetic composition of the fish. Hence the domesticated tilapia fish from the selected reservoirs have not undergone changes in their meristic or genetic characters with compared to the brood stock.

Three haplotypes (F, G and $\mathrm{H})$ belonging to Polonnaruwa district did not overlap with the other six haplotypes. The deviation of the three haplotypes may also be due to the low number of samples under each haplotype $(\mathrm{F}=$ $2 \mathrm{n}, \mathrm{G}=1 \mathrm{n}, \mathrm{H}=2 \mathrm{n}$ ) that would have not facilitated a fair distribution of samples among the groups for the analysis. However, Barlow, 1961; Ihssen et al. 1981; Lindsey, 1988 report that morphometric and meristic characters are only partially genetically determined and are strongly influenced by environmental conditions. Therefore the observed deviation with respect to meristic characters in the threehaplotype populations may be as a result of a genotypic interaction with the environment and hence the tilapias have not reflected a true meristic or population genetic partition. The repetitive stocking and harvesting of the tilapia would result a low probability in accumulating natural genetic mutations within a population. In such situations morphological markers are more applicable for studying short-term environmentally induced variation (Roby et al. 1991; Kinsey et al. 1994). Therefore a more detailed study with a higher sample number, on the interaction of the meristic characters with the limnological factors would give a clear understanding about the observed variability of the haplotypes with respect to meristic characters.

\section{Genetic diversity of domesticated tilapia in Sri Lanka}

Direct comparison between present findings and other studies on tilapia are difficult because of the scarcity of data based on SSCP method. Present findings show, higher haplotype diversities within brood stock compared with most test samples. This usually attributed to mixing of stocks during founding and subsequent propagation (Thompson, 1985; Ferguson, 1995).

Apart from the Udawalwe tilapia breeding centre, unique haplotypes were found in $\mathrm{Ku}$ runegala $(\mathrm{E})$ and Polonnaruwa $(\mathrm{F}, \mathrm{G}$ and $\mathrm{H})$. Following the stunting or dwarfism which was observed in the domesticated stocks of the introduced $O$. mossambicus fish (De Silva and Fernando, 1980) several batches of other cichlid species were introduced to the Sri Lankan freshwaters namely Tilapia hornorum, Tilapia rendali (Chandrasoma, 1983) before the introduction of $O$. niloticus. Many of these fish species were introduced to the Parakrama tank (Amarasinghe, 1997). The unintentional hybridization between the species (Macaranas et al. 1995) may have enhanced the stocks variability, which has resulted in the occurrence of unique haplotypes.

Previous studies (Daget and Moreau, 1981; Taniguchi et al. 1985) have shown reduction of growth performance in farmed populations of hybrids in tilapia. However, there has been no evidence to show impact of such hybridization in Sri Lanka. In view of the fact that many riverine species have invaded manmade lakes in Sri Lanka (Fernando and Indrasena, 1969; Schiemer and Hofer, 1982; De Silva, 1988) it is important to assess the genetic makeup prior to impoundment of stocks so as to preserve the integrity of existing stocks of fish, both native and exotic. 


\section{CONCLUSION}

PCR-SSCP of the $m t$-DNA $16 \mathrm{Sr}$ region, revealed eight haplotypes having overlapping patterns in the distribution of molecular genetic variation in populations of tilapia in Sri Lanka. Kurunegala, Anuradhapura and Polonnaruwa districts and Udawalwe brood stock share predominately, the mitochondrial $16 \mathrm{~S}$ haplotypes B and C. Haplotype -Ell was found only in Kurunegala at a frequency of $10 \%$ while $-\mathrm{F}\|,-\mathrm{G}\|$ and $-\mathrm{H} \|$ only in Polonnaruwa less than $6 \%$ each. Out of ten brood stock samples, $40 \%$ belong to haplotype -B\| and $20 \%$ to $-\mathrm{Cll}$. The remaining four belongs to A $(30 \%)$ and D (10\%). With respect to the meristic characters of the identified haplotypes, A, B, C, D and E haplotype groups broadly overlapped between the groups while F, G and $\mathrm{H}$ haplotypes identified from Polonnaruwa showed a deviation.

It would be valuable to conduct further studies with other variable genetic markers on a broader geographic scale would be particularly important in order to evaluate the population structure of this species. Therefore the results of this study are useful as baseline information of tilapia populations to contribute important insights into the domestication process and provide information that is essential for the effective management of domesticated tilapia stocks in this country.

\section{REFERENCES}

Amarasinghe US and De Silva SS 1996 Effect of Oreochromis niloticus and Oreochromis Mossambicus (Pisces: Chichlidae) hybridization on population reproductive potential and long term influence on reservoir fishery. Fish manag. Ecol. 3: 239- 249.

Amarasinghe U S 1997 Observations on the trends in the cilchild fishery fishery in an ancient reservoir in Sri Lanka. $J$, Nat. Res. Rese. Dev. Ag. Sri Lan. 35;
57- 68

Aurelle D and Berrebi P 2001 Genetic structure of brown trout (Salmotrutta L.) populations from south-western France: data from mitochondrial control region variability. Mol. Ecol. 10: 1551-1561.

Barlow GW 1961 Causes and significance of morphological variation in fishes. Syst. Zool. 10: 105-117.

Bronte CR, Fleischer GW, Maistrenko SG and Pronin NM 1999 Stock structure of lake Baikal Omul as determined by whole body morphology. J Fish Biol. 54: 787798.

Cadrin SX and Silva VM 2005 Morphometric variation of yellow tail flounder ICES $J$ Mar Sci. 62: 683-694.

Chandrasoma J 1983 Observations on fish introductions in some reservoirs of Sri Lanka.J. Inland Fish.2: 57-62.

Creech S 1992 A multivariate morphometric investigation of Atherinaboyeri Risso. 1810 and A. presbyter cuvier 1829 (Teloostei: Atherinidae) morphometric evidence in support of the two spiecies. J Fish boil. 41: 341-353.

Daget J and Moreau J 1981 Hybridization introgressive entre deuxespecies de Sarother odon (Pisces. Cichlidae) dansunelac de Madagascar. Bulletin $d u$ Museum National d'Histoire Naturelle (France) 3: 689-703.

De Silva CD 1997 Genetic variation in tilapia populations in man-made reservoirs in Sri Lanka. Aquaculture International, 5: 339-349.

De Silva SS 1988 Reservoirs of Sri Lanka and their fisheries.FAO Fisheries Technical Paper 298, 128.

De Silva SS and Fernando CH 1980 Recent trends in the fishery of ParakramaSamudra, an ancient man-made lake in Sri Lanka. In Ecology and development, edited by Furtado JI. Kuala Lumpur, Malaysia, University of Malaya Press, pp. 927-937

Ferguson MM 1995 The role of molecular genetic markers in the management of 
cultured fishes. In: Carvalho GR, Pitcher TJ (Eds.), Molecular Genetics in Fisheries. Chapman and Hall, Great Britain, pp. 81-104.

Fernando CH and Indrasena HHI 1969 The freshwater fisheries of Ceylon. Bulletin of the Fisheries Station, Colombo, Sri Lanka, 20: 101-134.

Hockaday S, Beddow TA, Stone M, Hancock $P$ and Ross LG 2000 Using truss networks to estimate the biomass of Oreochromis niloticus and to investigate shape characters. J Fish Biol. 57:9811000.

Ihssen PE, Evans DO, Christie JA, Reckahnand WJ, Desjardine RL 1981 Life history, morphology, and electrophoretic characteristics of five allopatric stocks of lake whitefish (Coregonusclupeaformis) in the Great Lake region. Can. J. Fish. Aquat. Sci. 38: 1790-1807.

Kamal A and Mair GC 2005 Salinity tolerance in superior genotypes of tilapia, Oreochromis niloticus, Oreochromismossambicus and their hybrids. Aquaculture, 247: 189-201.

Kinsey ST, Orsoy T, Bert TM, Mahmoudi B, 1994 Population structure of the Spanish sardine Sardinellaaurita: natural morphological variation in a genetically homogeneous population. Mar. Biol. 118: 309-317.

Kirchoff S, Sevigny JM, Couillard CM. 1999 Genetic and meristic variations in the mummichog Fundulus hetero- clitus, living in polluted and reference estuaries. Mar. Environ. Res. 47:261-283.

Lindsey CC 1988 Factors controlling meristic variation. Fish Physiol. 11: 197-274.

Liu ZJ and Cordes FJ 2004 DNA marker technologies and their applications in aquaculture genetics. Aquaculture. 238:137.

Macaranas JM, Agustin LQ, Ablan MCA, Pante MJR, Eknath AE and Pullin RSV 1995 Genetic improvement of farmed tilapias: biochemical characterization of strain differences in Nile tilapia. Aquac. Int. 3: 43-54.

Machordom A, Suárez J, Almodóvar A and Bautista JM, 2000 Mitochondrialhaplotype variation and phylogeography of Iberian brown trout populations. Molecular Ecology. 9: 1324-1338.

Mamuris Z, Apostolidis AP, Panagiotaki P, Theodorou AJ and Triantaphllidis C 1996 Morphological variation between red mullet pupulations in Greece. $J$ Fish Biol. 52: 107-117.

Nyingi D, De Vos L, Aman R and Agnèse J F 2009 Genetic characterization of an unknown and endangered native population of the Nile tilapia Oreochromis niloticus (Linnaeus, 1758) (Cichlidae; Teleostei) in the Loboi Swamp (Kenya). Aquaculture. 297,

Roby D, Lambert JD and Sevigny JM 1991 Morphometric and electrophorectic approaches to discrimination of capelin (Mallotusvillosus) populations in the estuary and Gulf of St Lawrence. $\mathrm{Ca}$ nadian Journal of Fisheries and Aquatic Sciences 48: 2040-2050.

Roux C 1971 Révision des poissonsmarins de la famille des Batrachoididae de la côteoccidentaleAfricaine. Bulletin $d u$ Muséum National d'HistorieNaturelle. Zoologie, Sér. 2, (1970), 42: 626-643.

Schiemer F and Hofer R 1982 A contribution to the ecology of the fish fauna of the Parakrama Samudra reservoir. In: Limnology of Parakrama Samudra (ed. F. Schiemer.) Junk Publishers: The Hague, 135-154.

Sivasundar A, Bermingham E, Orti G 2001 Population structure and biogeography of migratory freshwater fishes (Prochilodus: Characiformes) in major South American river. Mol. Ecol. 10: 407-417.

Taniguchi N, Perez-Enriquez R and Nugroho E 2003 DNA markers as a tool for genetic management of broodstock for aquaculture. In: Shimizu N, Aoki T, Hirono I, Takashima F (Eds.), Aquatic 
Genomics - Steps Toward a Great Future. Springer, Tokyo, pp. 417-429.

Vences M, Thomas M, Van der Meijden A, Chiari Y and Vieties DR 2005 Comparative performances of the $16 \mathrm{~S}$ rRNA gene in DNA barcoding of amphibians. Frontiers in Zoology. 2, 5.

Vigilant L, Stoneking M, Harpending $\mathrm{H}$, Hawkes K and Wilson AC 1991 African populations and the evolution of human mitochon drial DNA. Science. 253: 1503-1507. 